\title{
Shaping eschatology within science and theology
}

M Pretorius ${ }^{1}$

(University of Pretoria)

\section{ABSTRACT}

\section{Shaping eschatology within science and theology}

Traditionally, questions about the reign of God, death and resurrection, God's judgment and eternal life, have belonged to eschatology, specifically as presented by Biblical scholars. At times, when eschatology has become a topic of debate, it has unfortunately, resulted in accusations and acrimony among scholars. Yet, the Bible is clear about what the end entails; whether that is towards the believer or non-believer. Furthermore, the relationship of theology and science on eschatology has hardly been a topic of discussion. However, in recent times, there have been serious attempts by modern scholars to find common ground between these two seemingly diverse disciplines when it comes to eschatology.

\section{INTRODUCTION}

According to Berkhof (1958:666), over the years, scholars have applied various names to the last locus of Dogmatics, of which de Novissimis or Eschatology is the most common. As such, the name "eschatology" is based on specific passages of Scripture that speak of "the last days" - eschatai hemerai, Isaiah 2:2; Micah 4:1; "the last time“ - eschatos ton chronon, 1 Peter 1:20, and "the last hour" eschate hora, 1 John 2:18. Although these expressions sometimes refer to the entire New Testament dispensation, they still embody an eschatological idea. Indeed, when one speaks of eschatology, one has in mind facts and events that connect with the second coming of Christ. As a result, this marks the end of the present dispensation which will, in turn, usher in the eternal future.

As derived from the word eschatology, it has traditionally meant the study of the end times. Accordingly, it has dealt with questions - from a Biblical view - on the consummation of history and God's completion of His work in the world. However, from a scientific view, according to Polkinghorne (1998:29), it concerns

1 Mark Pretorius is a PhD student in the Department of Dogmatics and Christian Ethics, with Prof Johan Buitendag as supervisor. 
itself with what one can learn, and extrapolate out of present physical process. Unfortunately, when cosmologists peer into the future through extrapolated information, their story is one of eventual futility rather than one of hope and fulfilment. As such, the principal role of science is to pose to theology, the question of what meaning there could be in the hopeful belief - according to the Christian view of eschatology - that "in the end all will be well".

Generally though, when it comes to the scientific study of eschatology Jackelén (2005:203), states that the relationship of eschatology and science has hardly been a topic of discussion until now. Furthermore, eschatology is more often that not only given in bibliographies at the end of encyclopaedias, articles or in monographs. Thus, one assumes that, whenever eschatology has sought dialogue partners outside its traditional field (of theology), it has generally turned to philosophy. Indeed, even occasionally to social ethics and to ecology, but hardly ever to the traditional natural sciences (see also Ratschow 1982: 361-363; Greshake 1995:398).

Traditionally, according to Jackelén (2005:199), questions about the reign of God, death and resurrection, God's judgment and eternal life have belonged to eschatology. Nonetheless, theologians too often speak rather objectively of the end or consummation of the world, and they generally do this without seriously asking what the future of the universe is likely to look like from a scientific perspective. However, some, like Moltmann (1973:137) have attempted this, and envisage what Jackelén (2005:203) calls, a cosmic eschatology, i.e., an eschatology that is synonymous with nature. The thinking behind this view is that eschatology must take nature into account when dealing with end-time scenarios although, usually, non-religiously. Further, Jackelén does correctly point out that eschatology and scientific questions do show points of contact first and foremost in cosmology. But, in her view, theology still does not pay enough attention to the paradigm shift from the closed cosmos of past studies, to the open universe of modern times (see also Koyré 1994). However, there have been recent attempts by modern scholars to find common ground between these two seemingly diverse subjects (see Polkinghorne and Welker 2000). As such, the following models present just two of many such attempts by scientists and theologians to find this commonality between these two fields of study. 


\section{A SCIENTIFIC MODEL OF ESCHATOLOGY}

One could ask: Is it at all possible to speak of something which might resemble a scientific eschatology? From a purely scientific view, some like Tipler (1988) and Dyson (1979) believe it is possible.

Given this, both Tipler and Dyson believe that eschatology should also be classified as a branch of physics, and not only as a branch of theology alone. Tipler (1988:12), for example, claims that the likelihood of the existence of God, of human free will and of eternal life after death can be proven by pure physics alone. He believes his model, The Omega Point Theory, provides him with the proof that God exists. The Omega Point theory is similar (with variations) to the model invented by Teilhard de Chardin (1975:268272) to describe the ultimate maximum level of complexityconsciousness, considered by him, the aim towards which consciousness evolves. For Teilhard de Chardin, rather than finding Divinity "in the heavens" he held that evolution was a process converging toward a "final unity", or the Omega Point, identical with the Eschaton and with God. According to Vernadsky (1945), the planet is in a transformative process, metamorphosing from the Biosphere, that is, the sphere of human habitation, into the Noösphere, that is, the sphere of human thought or consciousness.

As such, Tipler's eschatological model states that life is essentially an accumulation of information. As a result of this accumulation of information, and life's path towards the Omega point, it has to pervade and finally dominate, according to Tipler, the entire material universe. The Omega point itself, however, will be a place of maximum accumulation of information, and therefore it will be immanent as well as transcendent with relation to each point in space-time. Because of this, the Omega point will have the properties of personality, omnipresence, omniscience, omnipotence and eternity. Thus, theoretically, the universe exists only when the Omega Point also exists in this universe, and in a sense, decides reality.

Although it seems that Tipler tries not to equate the Omega Point Theory with Christianity, he does try to show that it harmonises with the basic ideas of almost all religions. He also often refers to the theology of Pannenberg (see Tipler 1988:305-327). Furthermore, Tipler tries to show: 
1. The universe must be fated to collapse in on itself;

2. Everything in the universe will eventually be incorporated into a single great computer;

3. This computer, essentially a universal mind, will be able to prolong its subjective experience to infinity as it approaches the final singularity.

Although the author has addressed Tipler's model as clearly one of the more expressive postmodern views being put forth by science, one does find it a little difficult to reconcile his model with the Biblical idea of the end-times, and the life to come. Although he uses words like omniscience, immanence and transcendence, in the author's view, his model has seemingly nothing to do with the Biblical idea of God or His qualities. For example, when it comes to the idea of the resurrection, Tipler (1988:220-227) states that one should see the Resurrection, in his view, as "an exact replica of ourselves, simulated in the computer minds of the far future". Accordingly, the next stage of intelligent life will be machines that process information. For Tipler, the extinction of humankind is $a$ logically necessary result of eternal progress. Thus, theoretically; in the distant future, a computer capacity will be available that would enable the perfect simulation (emulation) of all possible variants of the world and, thus, of the entire visible universe of all times. As such, a resurrection of the dead will occur "when the computer capability of the universe is so large that the capacity needed to store all possible human simulations is an insignificant fraction of the entire capacity". Thus, the physics of immortality does not concern itself with "immortality", or even the "Biblical idea" of a resurrection from the dead. Rather it concerns itself with the spontaneous reconstruction in the form of emulations: as if, "in the last moment" someone would build a super computer in which all images of human beings are as holograph programs.

In a lightly worded defence of Tipler's model, Pannenberg (1995:313) states that at first glance, Tipler's model might seem a little far-fetched. However, one must consider that Tipler seriously defines life as an information process. Secondly, one must take his broadly conceived notion of the computer as an information processing entity, far beyond the machines that one currently calls computers used everyday. Thus according to Pannenberg (1995:314), the Christian hope in the future is not dependant on the portrayal of 
this earthly corporeality being transferred to another life that is based on different processors. Furthermore, the hope of a resurrection does not rule out that God's power of life, which has been manifested in Jesus Christ, does govern the universe in ways that are so far unknown. As such, "we are not prohibited from making surmises, even if we do so by means of physics", according to Pannenberg (1995:314).

In contrast to Tipler, Dyson (1979:103) speaks neither of resurrection nor of eternal life. By using quantitative arguments, he wishes to explain that life and intelligence can survive without limits, and that communicating information is possible despite constantly increasing intergalactic distances. Fortunately, Dyson is conscious, unlike Tipler that he mixes "science" and "science fiction" in his reflections, but he does not consider this too problematic, as long as the science is precise and the fiction is probable. For example, if one links consciousness to molecule substances, then life will stop as soon as the necessary supply of free energy is consumed. If, on the other hand, as Dyson (1979:453) assumes, consciousness depends merely on the structure of the molecules, then life can seek all kinds of practical embodiments, such as an interstellar black cloud or a sentient computer, as in the model of Tipler. Indeed, Dyson sees the most probable form of future life in just such a cloud-type collection of dust particles, which, as carriers of positive and negative charges, organize themselves and communicate among themselves by using electromagnetic forces. The greatest problem with this model, according to Jackelén (2005:206), lies in the fact that the waste heat produced by the metabolism of life, cannot radiate away into space quickly enough. In defence, Dyson's solution to this difficulty is hibernation: The metabolism occurs periodically so during constant radiation of waste heat, active phases alternate with phases without metabolism. In this way, an unlimited survival is possible with finite energy, and subjective time is infinite.

In principle, Dyson (1979:459) says that even in an everexpanding universe, infinite communication of information at finite expenditures of energy is possible. He further states that amounts of energy the sun radiates in eight hours, is already enough to keep alive indefinitely a society with the degree of complexity that characterises current human development. Although Dyson stresses that despite the many equations he lists, he is unable to present an 
ultimate mathematical proof for these claims, he is, however, optimistically satisfied with his results. He states that "I have found a universe growing without limit in richness and complexity, a universe of life surviving forever and making itself known to its neighbours across unimaginable gulfs of space and time”. Thus in his later work, Dyson (1990:117) confidently says that science offers a solid foundation for a philosophy of hope

Although these models do sound probable scientifically, one could ask: In the face of the immensity of the universe, is eschatology not simply an anthropological particularism that has grown immeasurably overtime? From a purely cosmological perspective, Weinberg (1988:154) states that much in eschatology appears as an absurd exaggeration of how significant this earth is, which according to him "is just a tiny part of an overwhelmingly hostile universe". Weinberg continues: "The effort to understand the universe is one of the few things that lifts human life a little above the level of farce, and gives it some of the grace of tragedy". Monod's (1972:172-180) words are even more disillusioning, he thinks humans, must finally awaken from their age-old dreams and recognise their complete desolation and their radical alienation. Humanity, according to him, needs to recognise that it is alone in the unfeeling immensity of the universe out of which it emerged only by chance. Even though these conclusions drawn from cosmological theories are highly debatable scientifically and theologically, they nevertheless help one to understand how unnatural, and even how presumptuous, the postulate of a valid eschatology can seem from the cosmological perspective. In saying this, the author proposes that the only possible solution to the debate surrounding eschatology is to view it biblically, and theistically.

\section{A THEISTIC VIEW OF ESCHATOLOGY}

The author stated in the beginning, that a theistic world-view was the only way that one could possibly and rightly come to terms with the many conflicting views that abound about creation and humanity. In this light, Polkinghorne (1998:114) states that one of the important implications of a theistic view of reality is that it assigns total meaningfulness to the universe, and its history. The claim is that the world is truly a cosmos and not, in his view, "a tale told by an idiot". This is because God's will and purpose, and God's assurance of an eventual fulfilment, are behind all that is happening. The most obvious difficulty in proving this claim is the fact of death. Indeed, 
not only do all human lives come to a mortal end with much personal business and spiritual growth still unfinished and incomplete, but modern cosmology also assures that the universe has condemned itself to die over a timescale of tens of billions of years. The question is: how do these views from the natural sciences conflict or agree with the Biblical account of the end times.

Before one can answer this question, one needs to understand, according to Polkinghorne and Welker (2000:3), that both science and theology, speak about unseen realities during their rational discourse. Whether as a physicist one speaks of unseen quarks and gluons, or as a theologian, one speaks of the unseen reality of God, both are dealing with an element of faith in their studies. It is this element of faith that one needs, to study the demanding topic of eschatology, from both a scientific and a theological belief. However, there is one more aspect of eschatology that needs discussion, if one hopes to understand eschatology's relation to reality, and that is, its relationship to time and eternity.

\section{TIME AND ETERNITY: IT'S RELATIONSHIP TO ESCHATOLOGY}

In considering all said up to this point, one realises that the idea of time and its relation to eschatology and eternity is a much-neglected subject. However Moltmann in his book "Coming of God" tackles this subject vigorously, by arguing that one must distinguish between God's futurum and His adventus if one wants to understand more clearly, eschatology and time (see also Bracken 2003). Noting the difference, futurum represents linear time, meaning that the past and present represent movement into the future. However for Moltmann (1996:29), adventus presupposes discontinuity as well as continuity with the present and the past. Thus, in the view of Bracken (2003:381), adventus, or eschatological time, in contrast to linear time, represents something new that could not have been anticipated in terms of what now exists. For Moltmann then, eschatology, or the coming of God, is to be understood in terms of adventus, rather than futurum - although these terms both refer to the future, they are different.

For Bracken (2003:383), one of the key points made by Moltmann is that God will not simply come at the end of time to bring the cosmic process to an end, but likewise comes at every moment to those who are psychologically prepared to receive His 
divine presence, and to respond to it. Adventus then, presupposes God as a transcendent Being for those humans who are psychologically prepared for something new. In other words, God is in ongoing communication with humans, bringing about new things for both Him and them. For Moltmann (1996:23) "God's future is not that He will be as He was and is, but that He is on the move, and coming towards the World." Admittedly, according to Bracken (2003:384), Moltmann does not explicitly say here that God changes in this coming to the World, but it seems to be implied in his comments that God's future is not the same as His past and present. Moltmann thus asserts that the future, when understood as adventus rather than futurum, is God's mode of existence. Clearly, a study of time and eternity is necessary, if one desires a deeper understanding of eschatology, and the life to come.

\section{THE COMPLEXITIES OF TIME}

Before one can study time from a religious and scientific perspective, one has to first admit that God is outside time, that is, time does not control God. He is an eternally self-existing, selfdefining, living Being. Since He created time, one can think of past, present, and future as eternally present before His eyes. Craig (2001:217) puts it thus, "Since God never begins to exist nor ever ceases to exist, it follows that God is omni-temporal. He exists at every time that ever exists; that is, He endures throughout all eternity".

Consequently, God's actions in eternity can affect past, present, and future (as experienced by humankind) simultaneously. Thus, a certain action of God completed in the past can have continuing and lasting results. Indeed, other activities of God, such as His expressions of grace and mercy towards all, continue day after day. As a result, certain events, such as the "appointed" hour one dies or the "Day of Judgment", are fixed in the future, predetermined by God.

As a result, unlike God, humankind is - to a degree controlled by time.

The question one may now ask: Is time eternal, since it was stated that this age will end? Scripture is clear that there will be a final consummation of all creation (see Is 2:2; Mi 4:1; 1 Pt 1:20 1 Jn 2:18). 


\section{TIME, DEATH AND ETERNITY}

At this point, one may ask: What is death, and how is one to define it according to time? Various passages in Scripture speak of physical death; that is cessation of life in ones physical body. Indeed, Ecclesiastes 12:7 refers to death as separating body and soul (or spirit). In the New Testament, James 2:26 also speaks of death as separation of body and spirit: "As the body without the spirit is dead, so faith without works is dead".

What one is dealing with here is the cessation of life in its familiar bodily state. However, this is not the end of existence. As such, one must not think of life-and-death as existence and nonexistence, but rather as two different states of existence. Death is simply a transition to a different state of existence, and not, as some tend to think, extinction. But, if physical death is simply a transition from one mode of existence to another, how is time, as one understands it in this existence, related to the next existence? Or, will time cease to exist, just as life in the physical body ceases to exist?

According to Craig (2001:218), space and time came into being with the creation of the universe, which implies, creation out of nothing (see also Barrow and Tipler 1986:442). As such, Hawking (1988:139), who was a proponent of infinite time, now acknowledges, that "almost everyone now believes the universe and time itself had a beginning at the big bang", Seemingly, this consensus lends strong support to the view that neither events nor time, existed before creation. As Parks (1981:112-113) states, "It is deceptively easy to imagine events before the big bang..., but in physics there is no way to make sense of these imaginings". One may ask: What then is one to make of these findings as it relates to eschatology and the end of humanity?

Before one can successfully answer this question, one needs to ask: If time is finite and began at the big bang, what existed before time, or, what state did God exist in before time began?

As stated, with the creation of the universe, time began. Subsequently, God entered time at the moment of creation in virtue of His real relations with the created order (see Craig 2001:233). As a result, one can speculate that not only is God timeless without the universe, but He is now also temporal with the universe. Indeed, theoretically, there seems to be two phases of God's life, a timeless phase and a temporal phase. But, according to Craig (2001:233), 
logically this is confusing, since to stand in relation of earlier than is by all accounts to be temporal (see also Leftow 1991).

The question is: How is one to escape this seeming antinomy? One possibility is to look at time from the view of not being divisible, a sort of undifferentiated time. Craig (2001:233) refers to it as amorphous time. Thus, the argument would then be compatible with the existence of amorphous time, before creation. Indeed, one could say: God existing alone without the universe, would exist in an amorphous time before the beginning of divisible time as it is known (see also Lucas 1973:311-312;Padget 1992:122-146; Swinburne 1993:204-222).

Such an understanding of God's time before creation seems attractive, as it enables one to speak literally of God existing before creation. It also seemingly avoids the problematic claim that God has endured through infinite time prior to creating the universe. It also confirms the claim from Scripture that one will live forever, even though one dies physically in the natural realm. Thus, the fact of a new creation, with a timeless state of being, means the Christian has a hope and a future that will doubtless be spent timelessly in the presence of God. One can say that this is the final consummation of death, leading to an eternal life resurrection.

Despite all said, one is still left with the problem of reconciling the views of science and theology with regard to creation and the end-times. In the following section, these views will be explored, and consensus reached, where possible, on how each view interacts with each other.

\section{RECONCILING THE TWO VIEWS}

Despite attempts by believing scientists, philosophers, and theologians to resolve the differences between Christian faith and the account the natural sciences give of the evolutionary history and structure of the world and the universe, they have had only minimal success. Stoeger (2000:19) argues that science with its contemporary scientifically and technologically oriented culture strongly challenges Christian and other religious beliefs when it comes to visions of the afterlife, resurrection, and the new heaven and the new earth. Many in the scientific world consider any meaning or hope in an eventual destiny tied to such Christian conceptions to be pure illusion, without any shred of real foundation in reality. Furthermore, they say, it has no support from anything in experience. Many in the 
scientific disciplines believe they are simply projections of ones own yearnings for meaning and significance, or symbols embedded in the universe of cultural meaning one has settled, in order to live a happy and productive life. Thus they have little or no bearing on what the eventual fate of humanity and that of the universe will be. From all the signs one can gather from the neurosciences, biology, physics, astronomy, and cosmology, death and dissolution are the final words. There is no scientifically supportable foundation for the immortality of the soul, bodily resurrection after death, or a transformed new heaven and earth - unless one embraces models like those of Tipler and Dyson.

However, to balance this debate, Peters (2001:125), who has worked for nearly two decades in the science-religion dialogue states: When theologians deal with loci such as creation or anthropology, it does seem that success between current science and doctrinal understanding is within reach. Seemingly, quantum physics does offer openings to a non-mechanistic understanding of the world as God's creation. Big Bang cosmology also seemingly reinforces the temporal and historical picture of creation drawn by theology. Furthermore, what one learns in genetics and the neurosciences also tends to add to the Christian understanding of the human person as embodied. Thus consonance appears to come easy in these areas. However, this is not the case when it comes to eschatology. Here one finds only dissonance, not consonance. Why? Because every scientifically projected scenario, leads to a future of the physical world that will destroy all known life. With no life left in the cosmos, what sense does it make for theology to speak of resurrection to eternal life? Of all the Christian teachings, eschatology appears to be the most out of sync with the world as science knows it. Tanner (2000:222) states "If the scientists are right, the world for which Christians hold out hope ultimately has no future".

As a result, it appears that every aspect of scientific cosmology points to a negative future for life on planet earth or even for the cosmos as a whole. Today, earth is threatened by onslaught from asteroids and comets; and a major impact could destroy life as it is known. In five billion years, according to Peters (2001:125) it is predicted that the sun will have exhausted its inner core of hydrogen, expand into a red giant, envelope the inner planets, and destroy planet earth. The universe itself will eventually evanesce due to the 
law of entropy or, less likely, collapse into a fiery crunch and final conflagration. Under every scientific scenario the life-generating capacity of the natural world will end. No scientific scenario looks like the Christian vision of a new heaven and a new earth.

As such, science accurately depicts the fate of the world when left to its own devices. However, what it leaves out, according to Tanner (2000:222), is Divine influence to divert, or overcome, what one could legitimately expect to occur, if the world was left to its own principles of operation.

Thus, a theologian might argue that the world will not come to the expected end envisaged by scientists, because of the continuing influence of a good, life-affirming God in world processes. A theologian could also claim that the world will be led beyond the destruction to which it is heading of its own accord, by a God who, as Christians affirm, can bring something from nothing, and life from death. God might indeed use the old world's destruction, as the scientists describe it, as a purgative means to a new heaven and earth beyond the reach of the old world's own capacities. Destructing the world then, becomes in that case, a kind of world crucifixion that signals the death of death through divine power.

Furthermore, Tanner (2000:221) states, that by taking this type of strategy of response, a future-orientated eschatology escapes any direct challenge from scientific end-time scenarios. These scenarios or the reasoning that leads to them is simply incorporated, with suitable theological modifications, within the same barely modified eschatological perspective from which the theologian started. The basic shape of the eschatological perspective remains the same. At most, scientific prediction of a dire future encourages the trend in contemporary Christian eschatology away from optimistic assessments of what one can expect from natural processes apart from God's help.

As such, the consummation of the world is not brought about by the world. One might say that a gap exists between the results of world processes and the world's consummation. Thus, only God, with the power to reverse those results can bridge this gap. Only God then has the power to bring what is otherwise unexpected into existence; for example, a world that knows neither loss nor suffering (see Moltmann 1996). One could even say a grace-motored continuity, rather than a continuity of purely natural processes, spans 
the world as one knows it and the world to come. Presently, the world moves without any great interruption to its consummation but it does so only in virtue of Divine powers, not its own (see Rahner 1973:273-289).

Despite the fact that the sciences of biology, physics, astronomy, and cosmology do give one an idea of humanity's fate, that is death and dissolution, it is not the final destination of humanity, or creation as a whole. Paul the Apostle clearly states in Romans 8:18-23:

I consider that our present sufferings are not worth comparing with the glory that will be revealed in us.

The creation waits in eager expectation for the sons of God to be revealed.

For the creation was subjected to frustration, not by its own choice, but by the will of the one who subjected it, in hope that the creation itself will be liberated from its bondage to decay and brought into the glorious freedom of the children of God.

We know that all creation has been groaning as in pains of childbirth right up to the present time.

Not only so we ourselves, who have the first-fruits of the Spirit, groan inwardly as we wait eagerly for our adoption as sons the redemption of our bodies.

In these verses, Paul speaks of a twofold groaning of creation (v. 22), and of believers (v. 23). The creation (i.e., animate and inanimate nature) is subject to suffering and physical catastrophes because of human sin (v. 20). As a result, God has purposed that nature itself will be redeemed and re-created. There will be a new heaven and a new earth, a restoration of all things according to God's will (cf. 2 Cor 5:17; Gl 6:15; Rv 21:1, 5), when God's faithful children receive their full inheritance (vv. 14, 23).

The question one faces though is on what basis can one construct a theology of the eventual future? According to Peters (2001:126), the answer is clear that one must root a theology of the future in the Easter resurrection of Christ. Stoeger (2000:19) puts it this way; 
There is no scientifically supportable foundation for the immortality of the soul, the resurrection of the body and the person after death, a transformed new heaven and new earth... For Christians these have their basis in the revelatory events of Jesus' life, death and resurrection, and all that flows from them...

One could state it thus; what science can do is give information about the nature of the world to be transformed. But one must then rely on independent theological resources for the promise that such a transformation lies in the future.

\section{CONCLUSION}

In conclusion, one realises that there are several reasons for the current attention paid to eschatology; one is the rapid development of knowledge. It seem that as technology increases and the scientist and theologian is able to know more, many of the issues surrounding eschatology become obscure and difficult to deal with. At times eschatology, according to Erickson (2001:1160) has become a topic of debate, resulting in accusations and acrimony among scholars. Yet, the Bible is clear about what the end entails, whether that is towards the believer or non-believer. Clearly, according to Barrett (2004:158-159) there is much in the eschatological picture that is speculative, but it is reasonable speculation in keeping with the axiom that the Lord God perfects the creation with utmost love.

In saying this, Weder (2000:202) aptly sums up the views of eschatology as follows:

The coming of the kingdom of God, finally, is related by the parables of Jesus to the phenomenon of growth. This is perceived as another trace of creativity, which nourishes faith in the creative God. There is a family resemblance between the creative process of growth and the creativity of the kingdom to come. The phenomenon of growth points to two fundamental conditions of the universe described by natural science: the process of building up higher complexity in open systems and the openness of the universe, which is protected from chaotic deliberacy or chaotic indefiniteness by strange attractors and the capacity to self-organisation. Although the world to come cannot be grasped as a prolongation of this 
universe, although this universe is bound to finitude, its openness, ordered by attractors, may be seen as a metaphor of a freedom so attractive that it allows hope for the final creation of a new and free world of everlasting peace.

This theological conclusion grounds ones hope that God will break the limits of the mind's dependence on the body - a dependence that is ubiquitous in the present experience of the world. The Christian hope is that, by His grace, God will enable the continued existence of the self, with a non-physical body after the death of physical bodies. It also leads to hope that, although the universe shall surely be uninhabitable for human subjects at some point in the finite future, God will create a new heaven and a new earth in which human subjects can remain eternally in the divine presence.

\section{Consulted literature}

Barrow, J \& Tipler F 1986. The Anthropic Cosmological Principle. Oxford: Oxford University Press.

Berkhof, L 1958. Systematic Theology. Great Britain: The Bath Press.

Bracken, J A. 2003 Intersubjectivity and the Coming of God. Journal of Religion 83(3), 381-400.

Craig, W L 2001. Time and Eternity: Exploring God's Relationship to Time. Wheaton Illinois: Crossway Books.

Dyson, F J 1979. "Time without End: Physics and Biology in an Open Universe.” Reviews of Modern Physics 51(3), 447-460.

Greshake, G 1995. Eschatologie II. Die Geschichte des Traktares. Lexikon für Theologie und Kirche. 3rd ed. Vol. 3. Freiburg, Basel, Rom, Wien: Herder, 860-865.

Hawking, S 1988. A Brief History of Time. London: Bantam Books.

Jackelén, A 2005. Time and Eternity: The Question of Time in Church, Science, and Theology. Philadelphia: Templeton Foundation Press.

Koyré, A 1994. From the Closed World to the Infinite Universe. Baltimore, London: Johns Hopkins University.

Leftow, B 1991. Time and Eternity. Cornwell Studies in Philosophy of Religion Ithaca, N.Y.: Cornell University Press.

Lucas, J 1973. A Treatise on Time and Space. London: Methuen.

Moltmann, J 1973. The Crucified God, transl. R A Wilson and John Bowden, $2^{\text {nd }}$ ed. New York: Harper \& Row.

-, 1996. The Coming of God. Christian Eschatology, transl. Margaret Kohl Minneapolis: Fortress Press. 
Monod, J 1972. Chance and Necessity. Translated by Austryn Wainhouse. New York: Vintage Books.

Padget, A G 1992. God, Eternity, and the Nature of Time. New York: St Martin's.

Pannenberg, W 1995. Breaking a Taboo: Frank Tipler's: The Physics of Immortality. Zygon, 30(2), 309-314.

Parks, D, 1981. "The Beginning and End of Time in Physical Cosmology”, The Study of Time IV, J T Fraser, N Lawrence, and D Park (eds.) Berlin: Springer.

Peters, T 2001. Dialog: A Journal of Theology, 40(2), 169-174.

Polkinghorne, J 1998. Science and Theology. Minnesota: Fortress Press.

Polkinghorne, J and Welker, M 2000. The End of the World and the Ends of God: Science and Theology on Eschatology. Harrisburg: Trinity Press International.

Rahner, K 1973. Immanent and Transcendent Consumation of the World in Theological Investigation vol 10, transl. David Bourke London: Longman \& Todd.

Ratschow, C H 1982. Eschatologie viii Systematisch-theologisch. In Theologische Realenzyklopädie 10. Berlin New York: W de Gruyter, 334-63.

Stoeger, W R 2000. Scientific Accounts of Ultimate Catastrophes in our Life Bearing Universe: The End of the World and the Ends of God: Science and Theology on Eschatology. Harrisburg: Trinity Press International, 19-28.

Swinburne, R, 1993. “God and Time,” in E Stump (ed.) Reasoned Faith. Ithaca, N.Y.: Cornell University Press.

Tanner, K 2000. Eschatology without a Future: The End of the World and the Ends of God: Science and Theology on Eschatology. Harrisburg: Trinity Press International, 222-237.

Teilhard de Chardin, P 1975. The Future of Man. New York: Harper \& Row:

Tipler, F J 1988. "The Omege Point Theory: A Model of an Evolving God” in Physics Philosophy and Theology: A Common Quest for Understanding, edited by R J Russell, W R Stoeger, and G V Coyne (eds.). Vatican City State: Vatican Observatory, 313-331.

Vernadsky, V I 1945. The Biosphere and the Noösphere. American Scientist, Jan, 1-12.

Weder, H 2000. "Metaphors and Reality" The End of the World and the Ends of God: Science and Theology on Eschatology Harrisburg: Trinity Press International.

Weinberg, S 1988. The First Three Minutes: A Modern View of the Origin of the Universe. Rev. ed New York: Basic Books. 